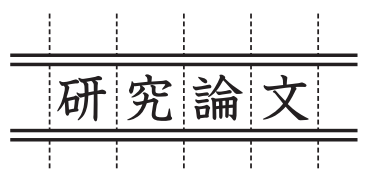

\title{
高密度バイオマスブリケット燃焼挙動へのブリケットサイズの影響
}

\section{Influence of Briquette Size on Combustion Behavior of Highly Densified Biomass Briquette}

伊東弘行*

Hiroyuki ITO

(Received January 12. 2016)

\begin{abstract}
To investigate the influence of briquette size on both flaming combustion and char combustion of highly densified biomass briquette, combustion experiments were carried out with the briquette made of cypress sawdust. In this study, three sizes of cylindrical briquette of which the ratio of height to diameter is kept at 2 ((1) $30 \mathrm{~mm}$ in diameter and $60 \mathrm{~mm}$ in height, (2) $35 \mathrm{~mm}$ in diameter and $70 \mathrm{~mm}$ in height and (3) $40 \mathrm{~mm}$ in diameter and $80 \mathrm{~mm}$ in height) were used as fuel samples. The density of the briquette and the moisture content are kept constant at $1300 \mathrm{~kg} / \mathrm{m}^{3}$ and $10 \mathrm{wt} \%$, respectively. A single briquette is inserted into the furnace to which preheated air $(673 \mathrm{~K}, 1.42 \mathrm{~m} / \mathrm{s})$ is supplied and the mass loss rate and each combustion duration were measured. As a result, in the flaming combustion duration, it is observed that the average mass loss rate $\left((\mathrm{dM} / \mathrm{dt})_{\text {mean }}\right)$ of briquette per specific surface area ( $\mathrm{S} / \mathrm{V}, \mathrm{V}$ : volume) is proportional to the surface area $(\mathrm{S})$ of the briquette. In the briquette size used in the study, it is demonstrated by introducing Fourier number that the flaming combustion duration $\left(\mathrm{t}_{\mathrm{f}}\right)$ is proportional to the square of an inverse number of the specific surface area $\left(t_{\mathrm{f}} \propto(\mathrm{V} / \mathrm{S})^{2}\right)$. The normalized mass loss rate $\left(\left(\mathrm{dM} / \mathrm{M}_{0}\right) /\left(\mathrm{dt} / \mathrm{t}_{\mathrm{f}}\right)\right)$ in the normalized flaming combustion duration for all three briquette size can be expressed in a single curve. It is shown that the char combustion duration ( $\mathrm{t}_{\mathrm{c}}$ ) is also proportional to the square of an inverse number of the specific surface area $\left(\mathrm{t}_{\mathrm{c}} \propto(\mathrm{V} / \mathrm{S})^{2}\right)$. For char combustion, shrinking-core reaction model was applied to the cylindrical briquette used in the study and the oxygen diffusion coefficients through both the gas boundary layer $\left(\mathrm{K}_{\mathrm{c}}\right)$ and the ash layer $\left(\mathrm{D}_{\mathrm{c}}\right)$ were determined by the experimental results. The oxygen diffusion coefficient through the ash layer $\left(D_{c}\right)$ is lower than that reported for lower density one and this may be attributed to the lower porosity of the highly densified briquette in this study. It is successfully demonstrated that the unburnt fraction in the normalized char combustion duration can be expressed by the model.
\end{abstract}

Key Words: Biomass Briquette, Combustion, High Density, Size

\section{1. 緒言}

近年、化石燃料の大量消費による資源の枯渇や地球温暖 化が問題になっている。とくに地球温暖化は、2015 年 11 月 30 日からフランス・パリで開催された第 21 回締約国会 議 (COP21) にて対策について協議される1) ど、地球規模 で関心を集めている。現在の地球温暖化の主要因とされる 温室効果ガスの中でも、二酸化炭素は主に化石燃料の燃焼 由来であることから、二酸化炭素排出量を削減できる代替 エネルギーが注目されている。エネルギー資源としてのバ イオマスの利用はそれら代替エネルギー、いわゆる新エネ ルギーのひとつに位置づけられている ${ }^{2)}$ 。植物由来のバイ オマスは、植物が大気中から吸収する二酸化炭素量と、そ の植物を燃焼した際に放出される二酸化炭素量を均衡させ る、すなわち大気中の二酸化炭素量を人為的活動によって 増大させないというカーボンニュートラルの概念から二酸 化炭素排出削減が期待され、様々な形態での利用が検討さ
れている ${ }^{3-5)}$ 。バイオマスは固体で存在するものが多く、バ イオマスを固体で利用することは、燃料の創出に大きな付 加的エネルギーを要しないという点で有利である。とくに 固体バイオマスを粉砕の後にペレットやブリケットなどに 圧密化することで、エネルギー密度を大きく出来るため貯 蔵や輸送に有利、燃料の均質化を図れるため燃焼制御が容 易になる、などのメリットがある。バイオマスブリケット 製造時に圧縮しながら加熱することで、密度拉よび機械的 強度をさらに増大させた高密度バイオマスブリケット（バ イオコークス：BIC）が開発されているの。バイオコークス は鉄溶解炉の石炭コークス代替燃料として開発されたもの であるが、高強度で崩れにくい、長期安定性がある》、高 エネルギー密度であるため貯蔵しやすく燃料投入頻度を少 なく出来るなどの特長から、暖房用など他の燃焼機器への 使用にもメリットがあると考えられる。バイオマスブリ ケットを燃焼利用する上で、その燃焼特性を理解すること は効率の良い最適な燃焼機器の設計という観点から非常に

* 神奈川大学 工学部 機械工学科（～221-8686 神奈川県横浜市神奈川区六角橋 3-27-1）

Department of Mechanical Engineering, Faculty of Engineering, Kanagawa University

(3-27-1 Rokkakubashi Kanagawa-ku, Yokohama, Kanagawa, 221-8686 Japan) 
重要であるが、燃料製造・燃料強度評価等の観点から多く の研究が行われている ${ }^{8-10)}$ 一方、ペレットやブリケットな どの燃焼研究は比較的少ないのが現状である。とくにブリ ケット製造時に、圧縮と同時に $423 \mathrm{~K}$ 程度に加熱する高密 度ブリケットについては、燃焼挙動への空気流量の影響 ${ }^{11)}$ 、

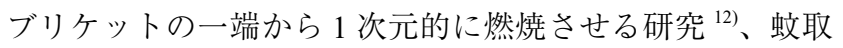
り線香を原料として密度の影響を調べた研究 7)などが見ら れるが、暖房用などの燃焼機器での利用を想定した研究は 数少ない。

本研究では、ヒノキおがくずを原材料とし、ブリケット 製造時に圧縮とともに加熱を行った高密度バイオマスブリ ケットの有炎燃焼（気相燃焼）、チャー燃焼時それぞれの燃 焼挙動（質量減少および燃焼継続時間）へのブリケットサ イズの影響を調べることを目的とした。有炎燃焼では、従 来の多くの研究 ${ }^{13-14)}$ において有炎燃焼時の平均質量減少速 度を調べているが、同燃焼区間の質量減少速度を注意深く 観察すると、質量減少速度は一定ではなく時間変動してい ることがわかる。燃焼速度(質量減少速度)の時間的変動は、 ブリケット燃焼時の発熱速度変動を意味し、ブリケットの 燃焼挙動を詳細に捉えるためには、質量減少速度の時間変 化を明らかにする必要がある。本研究では、とくに有炎燃 焼区間、チャー燃焼区間それぞれにおける質量減少速度の 時間変化を調べ、これらに対するブリケットサイズの影響 を調べた。

\section{2. 実験試料}

バイオマス原料には、島根県産ヒノキのおがくずを使用 した。おがくずを粉砕機（シニオン株式会社：HS-10）で 30 秒間粉砕し、バイオマスペレット水分計（佐藤商事： B1）を用いて初期水分を調整した後に円筒形状のブリケッ ト製造モールドに充填する。油圧プレスにて所定の圧力ま で圧縮し、圧力を一定に保持したまま管状電気炉でモール ドを覆い、 $423 \mathrm{~K}$ で 15 分間加熱する。その後室温になるま で冷却した後にブリケットをモールドから取り出した。本 研究では、密度 $1300 \mathrm{~kg} / \mathrm{m}^{3}$ 程度および水分率 $10 \%$ 程度に 調整し、ブリケット寸法を、直径：長さ比を一定とし $\phi 30$ $\mathrm{mm} \times 60 \mathrm{~mm} 、 \phi 35 \mathrm{~mm} \times 70 \mathrm{~mm} 、 \phi 40 \mathrm{~mm} \times 80 \mathrm{~mm} の 3$ 種類 とした。各ブリケット寸法で 3 個ずつ試料を用意し、燃焼 実験を行った。

ヒノキおがくずの元素分析および工業分析結果を Table 1 およびTable 2 にそれぞれ示す。奥村らの結果(揮発分 $78.7 \%$ 、 固定炭素 $13.2 \%$ 、灰分 $0.2 \%)^{15)}$ と比べると、固定炭素拈よ び灰分がわずかに少ないが、揮発分が $80 \%$ 程度、固定炭素 分が $10 \%$ 程度でありほぼ同様であることがわかる。

\section{3. 燃焼実験装置}

本研究では、バイオマスブリケット単体を、昇温した空 気中で着火・燃焼させることが出来る燃焼実験装置を用い
Table 1 Ultimate analysis of cypress sawdust.

\begin{tabular}{|c|c|}
\hline $\mathrm{C}[\mathrm{wt} \%]$ & 50.55 \\
\hline $\mathrm{H}[\mathrm{wt} \%]$ & 6.32 \\
\hline $\mathrm{N}[\mathrm{wt} \%]$ & 0.07 \\
\hline $\mathrm{O}[\mathrm{wt} \%]$ & 33.62 \\
\hline
\end{tabular}

Table 2 Proximate analysis of cypress sawdust.

\begin{tabular}{|c|c|}
\hline Water content $[\mathrm{wt} \%]$ & 6.3 \\
\hline Volatile constituent [wt\%] & 80.5 \\
\hline Fixed carbon $[\mathrm{wt} \%]$ & 10.0 \\
\hline Ash content $[\mathrm{wt} \%]$ & 3.2 \\
\hline
\end{tabular}

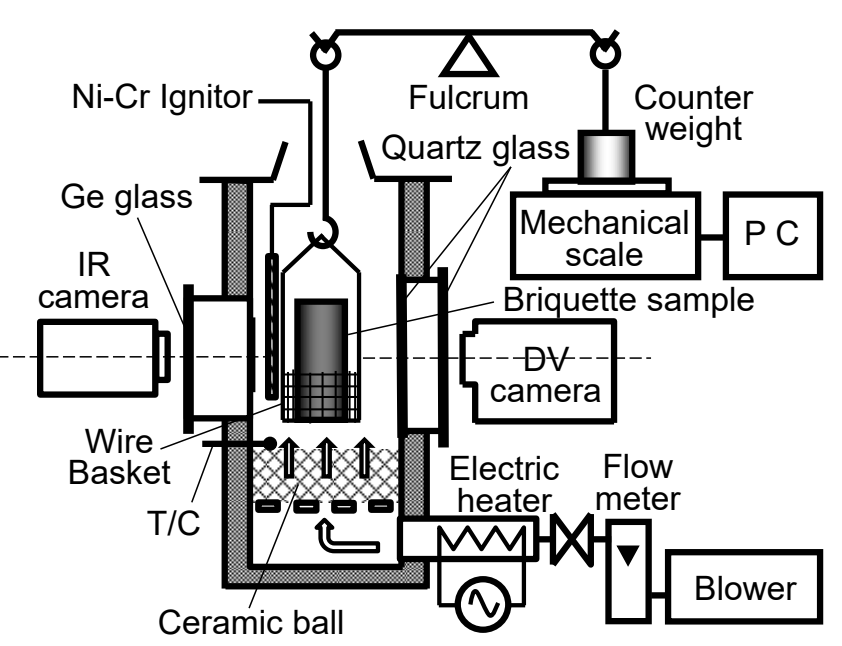

Fig.1 Experimental Setup.

た。Fig.1に実験装置概略を示す。燃焼炉本体は、内径 105 $\mathrm{mm} \times$ 外径 $120 \mathrm{~mm}$ (長さ $420 \mathrm{~mm}$ ）のムライト管を内筒と し、外径 $216.3 \mathrm{~mm}$ (内径 $208.3 \mathrm{~mm}$ ）のステンレス管を外 筒とする構造とし、内外筒の間に断熱材を充填した。ブロ ワから供給される燃焼用空気は流量を測定して電気ヒータ にて加熱された後、燃焼炉下方から供給される。燃焼炉下 方には直径 $10 \mathrm{~mm}$ のセラミックボールを充填し、燃焼炉内 への供給空気を整流した。本研究では、空気流量 $0.3 \mathrm{~m}_{\mathrm{N}}{ }^{3} /$ $\min$ 、空気温度 $673 \mathrm{~K}$ 一定とした（炉内平均空気流速 1.42 $\mathrm{m} / \mathrm{s}$ )。高温空気供給後、整流用セラミックボール下流の空 気温度が $673 \mathrm{~K} に て$ 安定を確認後、上部が開放されたかご 状の金網（ $\phi 35 \mathrm{~mm} \times 50 \mathrm{~mm}$ ( $\phi 30 \mathrm{~mm}$ ブリケット)、 $\phi 40$ $\mathrm{mm} \times 60 \mathrm{~mm}(\phi 35 \mathrm{~mm}$ ブリケット)、 $\phi 45 \mathrm{~mm} \times 70 \mathrm{~mm}(\phi 40$ $\mathrm{mm}$ ブリケット)、 5 メッシュ、線径 $0.75 \mathrm{~mm}$ ）に載せたブ リケットを炉内に挿入した。ブリケットを載せた金網を天 
秤の一方に吊るし、他方に錘を吊るして電子天秤（島津：

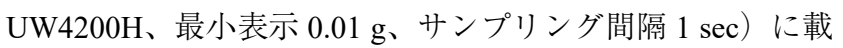
せることで、ブリケットの質量減少を測定した。ブリケッ 卜は炉内へ投入後、高温空気により加熱され表面着火およ び熱分解ガスの放出を開始するが、熱分解ガス放出後すぐ に有炎燃焼させるため、ニクロム線を通電加熱した強制着 火装置を用いた。着火装置は熱分解ガスに着火後、速やか にブリケット近傍から退避させた。燃焼挙動の直接映像を DV カメラで、ブリケットの表面温度を IR カメラで監視、 撮影した。 $\phi 30 \mathrm{~mm} \times 60 \mathrm{~mm} 、 \phi 40 \mathrm{~mm} \times 80 \mathrm{~mm}$ の 2 種類の ブリケットについて、有炎燃焼時の内部温度変化を調べる ため、それぞれ 3 本の $\mathrm{K}$ 型シース熱電対（外径 $1 \mathrm{~mm}$ ）に て各ブリケット軸方向中央位置の温度を計測した。熱電対 はブリケット上部より挿入し、温度測定位置は、(1)ブリ ケット中心 $(\mathrm{r}=0 \mathrm{~mm}) 、(2) \mathrm{r}=6 \mathrm{~mm}(\phi 30 \mathrm{~mm}) 、 8.5 \mathrm{~mm}(\phi 40$ $\mathrm{mm}) 、(3 \mathrm{r}=12 \mathrm{~mm}(\phi 30 \mathrm{~mm}) 、 17 \mathrm{~mm}(\phi 40 \mathrm{~mm}))$ の 3 点とした。

\section{4. 全体燃焼挙動へのブリケットサイズの影響}

$\phi 30 \mathrm{~mm} \times 60 \mathrm{~mm} 、 \phi 35 \mathrm{~mm} \times 70 \mathrm{~mm} 、 \phi 40 \mathrm{~mm} \times 80 \mathrm{~mm}$ の 3 種類のブリケットをそれぞれ単体で然焼炉に投入し、 着火から燃え切りまでの燃焼挙動を観察した。全てのブリ ケットで、まず炎を伴わない表面着火が見られ、その後気 相着火して有炎燃焼するのが観察された。有炎燃焼が終了 後、チャー燃焼へ移行した。Fig.2に、各ブリケットサイズ における炉内投入時からの経過時間とブリケット質量減少 量の関係を示す。全てのブリケットにおいて最初に見られ る傾きの大きな質量減少は気相燃焼区間（ $830 \mathrm{~mm}$ では $45 \mathrm{~g}$ 程度まで、 $\phi 35 \mathrm{~mm}$ では $70 \mathrm{~g}$ 程度まで、 $\phi 40$ では $100 \mathrm{~g}$ 程度 まで）であり、その後の緩やかな傾きの質量減少はチャー

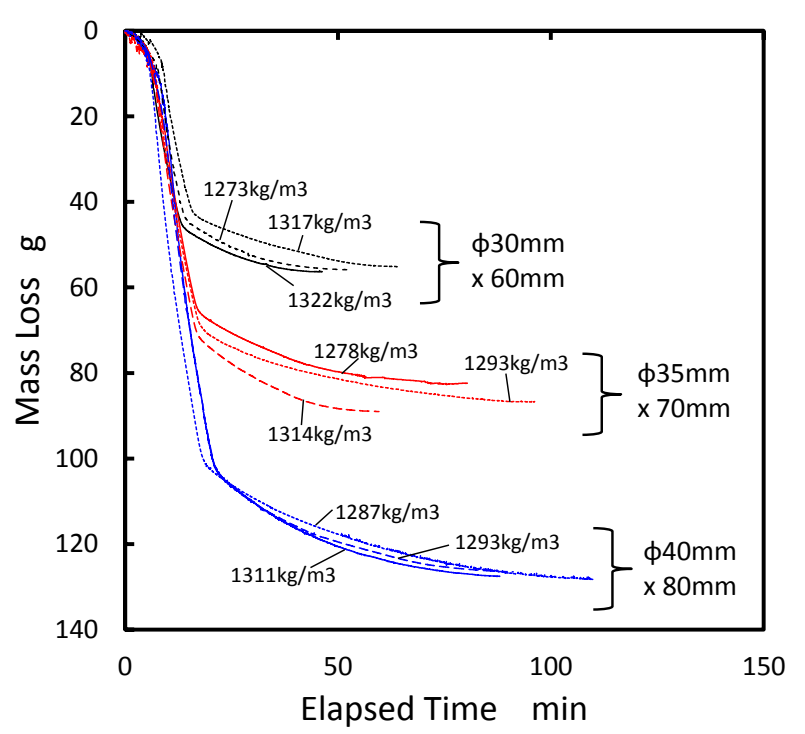

Fig.2 Mass Loss Behavior of Each Briquette.
燃焼区間を表している。ブリケットサイズが大きいほど総 質量が大きいため質量減少量が大きく、総燃焼時間も長い ことがわかる。それぞれのブリケットサイズにおけるバラ つきを比較すると、着火時間などに若干の個体差が見られ るものの概ね同様の挙動を示していることがわかる。

ブリケット質量減少速度の時間変化を調べるため、Fig.2 の質量減少の傾きから各時間における質量減少速度を算出 した。各ブリケットサイズにおける炉内投入時からの経過 時間に対する質量減少速度を Fig.3に示す。計算には質量 減少量の 60 点移動平均を用いた。図より、ブリケットサ イズの大きい方が、質量減少速度が大きくなるのがわかる。 とくに有炎燃焼時 $(\phi 30 \mathrm{~mm}$ では $14 \mathrm{~min}$ 程度まで、 $\phi 35 \mathrm{~mm}$ では $18 \mathrm{~min}$ 程度まで、 $\phi 40 \mathrm{~mm}$ では $22 \mathrm{~min}$ 程度まで）の質 量減少速度に大きな違いが見られる。

\section{5. 有炎燃焼時の燃焼挙動}

\section{1 有炎燃焼時の質量減少速度}

有炎燃焼時の平均質量減少速度を算出するため、O. C. Chin ら $^{13)}$ や J. Chaney ${ }^{14)}$ の研究と同様、Fig.2のグラフの傾 きを調べた。有炎燃焼時の質量減少は、主にブリケットが 加熱されることによる揮発分の放出であると考えられる。 従って、ブリケットの加熱条件（火炎温度や火炎のブリケッ ト表面からの距離、周囲ガス流速など）に大きな違いがな ければ、ブリケットへの入熱、ひいてはブリケットの平均 質量減少速度が加熱面であるブリケット表面積に比例する と予想される。本研究で使用したブリケットはそれぞれ比 表面積が異なるため、それぞれの比表面積で除すことで単 位比表面積あたりの平均質量減少速度を求め、表面積との 関係を Fig.4 として示した。 $(\mathrm{dM} / \mathrm{dt})_{\text {mean }}$ は有炎燃焼時の平 均質量減少速度 $[\mathrm{g} / \mathrm{min}] 、 \mathrm{~S}$ はブリケット表面積 $[\mathrm{m}] 、 \mathrm{~V}$ は ブリケット体積 $\left[\mathrm{m}^{3}\right]$ を表す。Fig.4より、単位比表面積あ

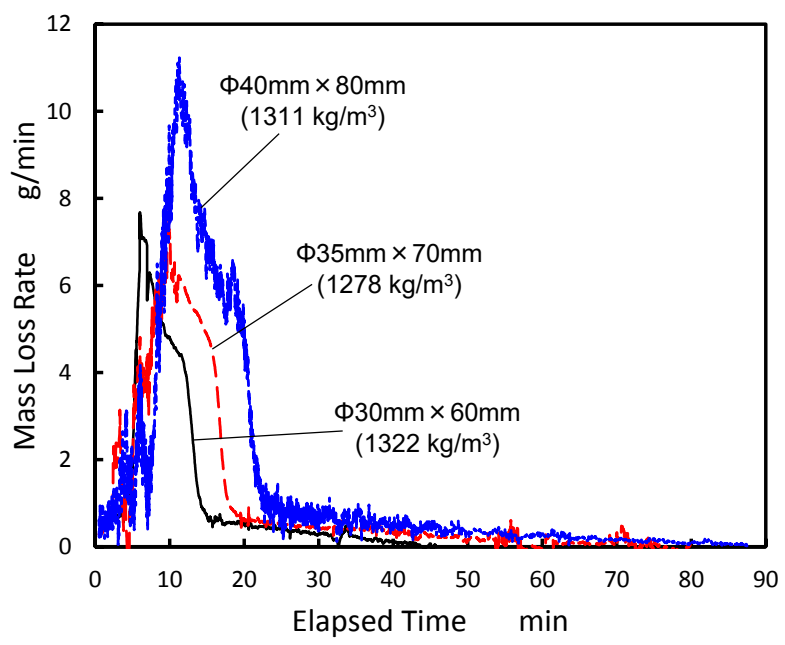

Fig.3 Mass Loss Rate. 


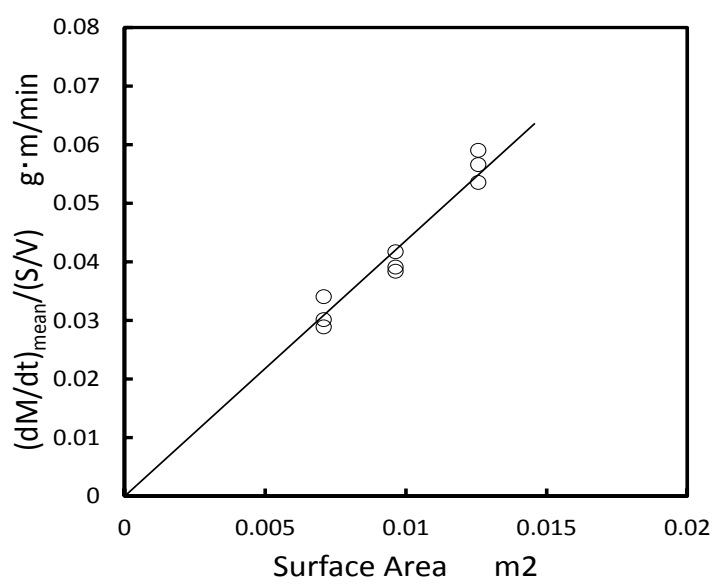

Fig.4 Relationship between Mass Loss Rate for Specific Surface Area and Briquette Surface Area.

たりの平均質量減少速度は、本研究の範囲では表面積に比 例することがわかる。またこのことは、ブリケット周囲に 形成される火炎の状態がブリケットサイズに大きく依存し ないことを示唆している。

\section{2 有炎燃焼継続時間}

上述したように、有炎燃焼では質量減少がブリケットへ の入熱により支配されると考えられる。本研究のようにブ リケット外面から加熱され、かつ着火源がブリケット周囲 に存在する場合、有炎燃焼の開始時期は、ブリケット表面 側での熱分解により放出される揮発分が周囲空気と混合し て可燃混合気を形成するまでの時間で決定される。一方、 有炎燃焼の終了時期は、ブリケット中心部からの揮発分の 放出が終了し可燃混合気を形成できなくなる時間で決定さ れる。すなわち有炎燃焼の継続時間は、ブリケット表面が 熱分解温度に加熱された後にブリケットの中心部が熱分解 終了温度に達するまで加熱されるのに要す時間により決定 される。本研究のように、同じ物質かつ密度がほぼ同様で 大きさの異なるブリケットの中心部を同じ温度まで加熱す るのに要する時間は、以下に示すフーリエ数 : $F_{0}$ を同じと して考えることができる ${ }^{16)}$

$$
F_{0}=\frac{\alpha_{s} t}{L^{2}}
$$

ここで、 $\alpha_{\mathrm{s}}$ : 温度伝導率 $\left[\mathrm{m}^{2} / \mathrm{s}\right] 、 t$ : 時間 $[\mathrm{s}] 、 L$ : 代表寸法 $[\mathrm{m}]$ である。本研究で使用したブリケットにおいて、代表寸法： $L=V / S$ と考え、また密度がほぼ同様であることから温度伝 導率： $\alpha_{\mathrm{s}}$ 一定の場合には、有炎燃焼継続時間 : $t_{\mathrm{f}}$ は、

$$
\mathrm{t}_{f} \propto\left(\frac{V}{S}\right)^{2}
$$

と考えることができ、 $(\mathrm{V} / \mathrm{S})^{2}$ に比例すると予想される。本

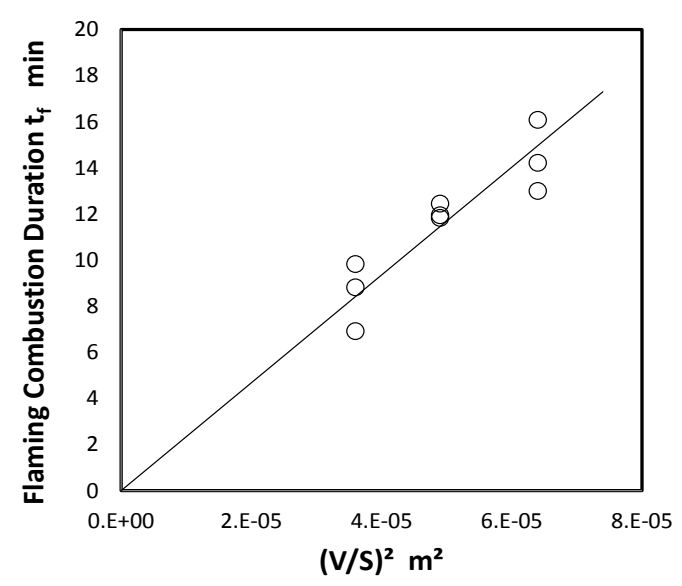

Fig.5 Flaming Combustion Duration.

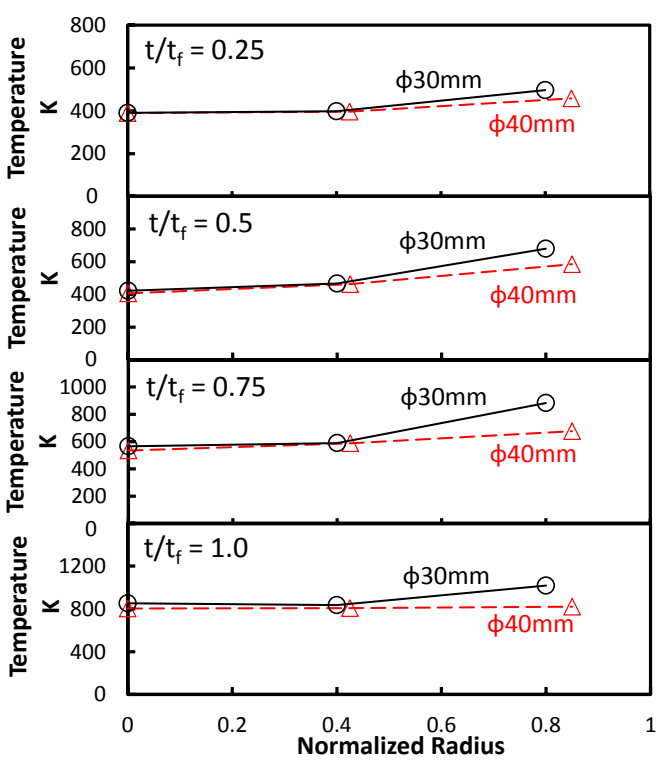

Fig.6 Normalized Temperature Distribution.

研究で得られたそれぞれのブリケットサイズにおける有炎 燃焼時間を $(\mathrm{V} / \mathrm{S})^{2}$ に対してプロットした結果を Fig.5に示 す。本研究の範囲では有炎燃焼時間は $(\mathrm{V} / \mathrm{S})^{2}$ にほほ比例し ており、この結果からも有炎燃焼がブリケット内部の熱移 動に支配されていることが窅える。

ブリケットサイズによらずフーリエ数が一定になること は、ブリケット内部の無次元温度分布が同様になることを 示唆している。本研究では、ブリケット内部温度分布を確 認するため、ブリケットに熱電対を挿入して内部温度を測 定した。 $\phi 30 \mathrm{~mm} \times 60 \mathrm{~mm}$ ブリケットと $\phi 40 \mathrm{~mm} \times 80 \mathrm{~mm}$ ブ リケットの各測定点における無次元時間（経過時間を有炎 燃焼時間で除す）が $0.25,0.5,0.75,1.0$ のときの無次元半径 位置における温度を Fig.6に示す。横軸の無次元半径の 0 がブリケット中心、1 がブリケット外周面を表す。Fig.6よ 


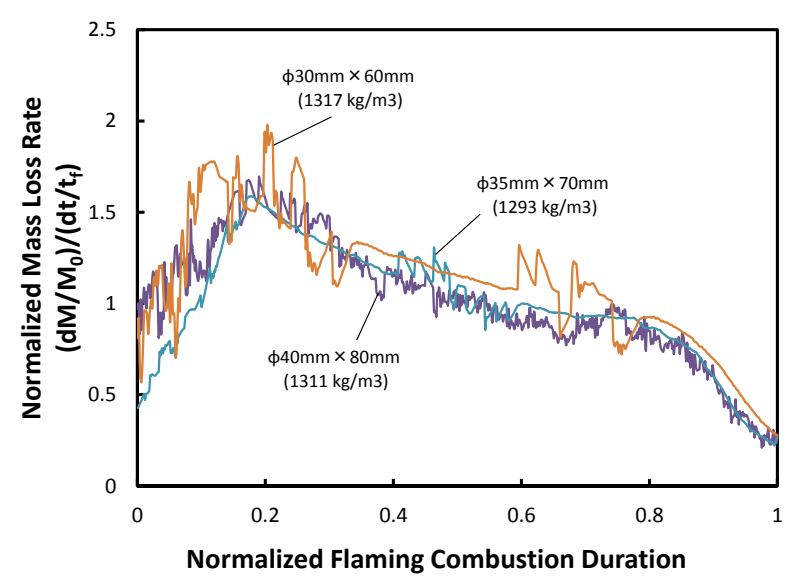

Fig.7 Normalized Mass Loss Rate of Briquette in Flaming Combustion.

り、無次元温度分布は小さいブリケット $(\phi 30 \mathrm{~mm})$ の方が ブリケット外周側で大きくなる傾向が見られるが、ブリ ケット中心側の無次元内部温度分布はほぼ同様であること がわかる。実際のブリケット内部の温度分布は完全に相似 ではないが、この中心側の無次元温度分布がブリケットサ イズによらずほぼ同様であることが、フーリエ数を同じと して有炎燃焼継続時間を扱える効果をもたらしていると考 えられる。

\section{3 有炎燃焼時の無次元質量減少速度}

Fig.3に示したように、有炎燃焼時の質量減少速度は一 定ではなく、時間とともに大きく変化する。従って、従来 の研究 ${ }^{13-14)}$ のように、有炎燃焼時の平均質量減少速度の情 報のみでは不十分である。ブリケットの燃焼速度、ひいて は発熱速度を予測するためには、燃焼経過時間に対するブ リケット質量減少速度を詳細に把握する必要がある。サイ ズの異なるブリケットについて、初期ブリケット質量で質 量減少速度を無次元化した無次元質量減少速度を縦軸に、 有炎燃焼時間で経過時間を無次元化した無次元時間を横軸 にとりプロットしたものを Fig.7に示す。図より、無次元 質量減少速度は、ブリケットサイズによらずほぼ同様であ り、1つの曲線で表せることがわかる。従って、本研究で 用いたような直径対長さ比の高密度ブリケット $(\phi 30 \mathrm{~mm} \times$ $60 \mathrm{~mm} \sim \phi 40 \mathrm{~mm} \times 80 \mathrm{~mm})$ を同様の条件で然焼する際には、 Fig.5の関係から有炎燃焼継続時間を、Fig.7の関係から有 炎燃焼時の質量減少速度を予測することが出来る。

\section{6. チャー燃焼時の燃焼挙動}

\section{1 チャー燃焼継続時間}

有炎燃焼終了後のチャー燃焼では、有炎燃焼とは異なり、 周囲空気からブリケット内部への酸素の拡散が燃焼速度に 対し支配的となる ${ }^{17)}$ 。密度: $\rho\left[\mathrm{kg} / \mathrm{m}^{3}\right]$ 、体積: $\mathrm{V}\left[\mathrm{m}^{3}\right]$ のブリケッ トを時間 : $\mathrm{t}_{\mathrm{c}}[\mathrm{s}]$ で然焼する速度はブリケット内部への供給

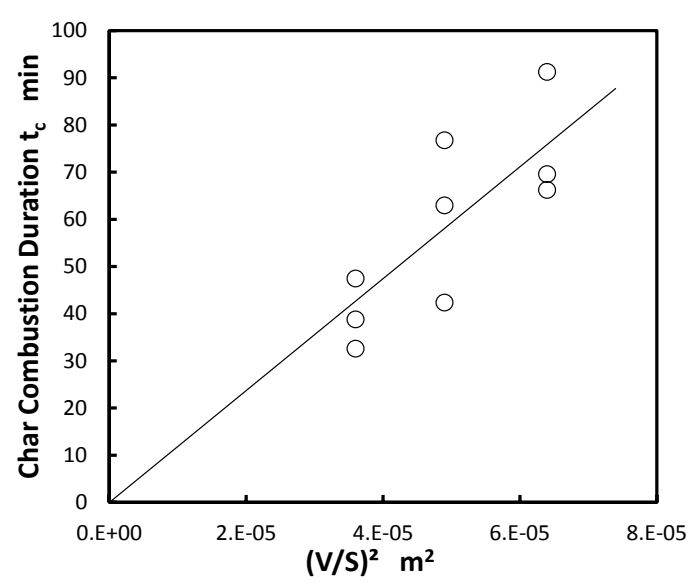

Fig.8 Char Combustion Duration.

酸素流束：m $[\mathrm{kg} / \mathrm{s}]$ に比例する。物質移動における質量流 束は熱移動における熱流束と同様の式 ${ }^{16)}$ で表され、

$$
\dot{\mathrm{m}}=\mathrm{D} \frac{\partial \rho}{\partial x} S
$$

となるが、ブリケット密度が一定 $\left(1300 \mathrm{~kg} / \mathrm{m}^{3}\right)$ であること から拡散係数：D $\left[\mathrm{m}^{2} / \mathrm{s}\right]$ を一定と仮定すると、ブリケット 内燃焼部へ供給される酸素の質量流束はブリケット表面か ら燃焼部までの距離 : $\mathrm{x}$ [m] に反比例するので、

$$
\mathrm{m} \propto \frac{S}{\mathrm{x}}
$$

と表すことが出来、さらに $\mathrm{x} \equiv \frac{V}{S}$ とすれば、チャー燃焼 継続時間 : $\mathrm{t}_{\mathrm{c}}[\mathrm{s}]$ は、

$$
\begin{aligned}
t_{c} & \propto \frac{V}{\mathrm{~m}} \\
& \propto\left(\frac{V}{S}\right)^{2}
\end{aligned}
$$

と表すことができ、有炎燃焼継続時間と同様、 $(\mathrm{V} / \mathrm{S})^{2}$ に比 例すると予想される。本研究で得られたそれぞれのブリ ケットサイズにおけるチャー燃焼時間を $(\mathrm{V} / \mathrm{S})^{2}$ に対してプ ロットした結果を Fig.8に示す。Fig.8より、データのバ ラつきが若干大きいが、本研究の範囲内では概ねチャー燃 焼継続時間は $(\mathrm{V} / \mathrm{S})^{2}$ に比例することがわかる。チャー燃 焼では、燃焼が進行する過程で時折燃焼終了後の灰が剥が れ落ちる、また部分的に亀裂が入る、などの挙動が見られ た。これらのことがブリケット未燃部への酸素供給状態を 変え、チャー燃焼時のそれぞれのブリケットの個体差とな りデータにバラつきを生じる要因になっていると考えられ る。

\section{2 未反応核モデルを用いた検討}

チャー燃焼における質量減少について未反応核モデル ${ }^{17)}$ 


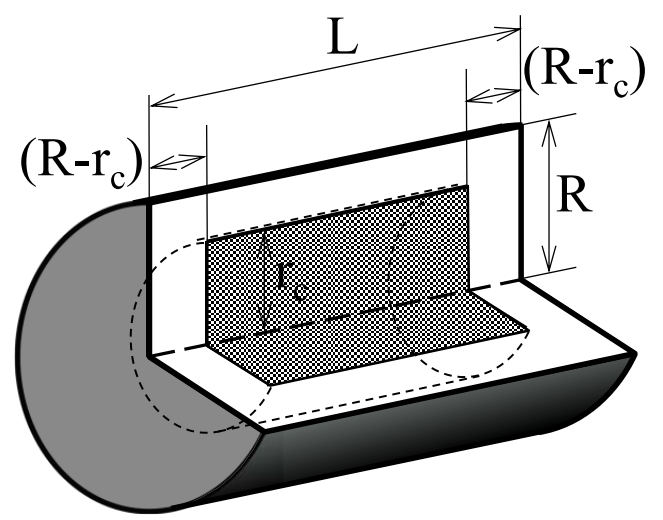

Fig.9 Shrinking Core Model.

の適用を検討した。本研究で使用したブリケットは円柱形 状であるため、J. Porteiro ら ${ }^{18)}$ が円柱木材の燃焼モデルに 用いたモデルと同様に Fig.9 に示すように燃焼面が進行す ると仮定した。すなわち燃焼面の進行は円柱側面への速度 で進行し、両端部（円形端面）でも円柱側面と同じ速度で 進行するものとした。

半径 : R [m]、長さ : L [m] の円柱試料について、ガス境 膜における酸素の移動係数：Kc および兏層中における酸素 の有効拡散係数：Dc を考慮すると、チャー燃焼の反応時間： $\mathrm{t}$ は以下の式で表すことが出来る。

$$
\begin{aligned}
t= & \frac{C_{B}}{L C_{0}}\left[( 1 - \frac { r _ { c } ^ { 2 } } { R ^ { 2 } } ) \left[\frac{(L-2 R) R}{2 K_{c}}\right.\right. \\
& \left.+\frac{R^{2}}{2 D_{c}}\left\{\frac{L-2 R}{2}+(L-2 R) \ln R\right\}\right] \\
& +\left(1-\frac{r_{c}^{3}}{R^{3}}\right)\left\{\frac{R^{2}}{K_{c}}+\frac{R^{3}}{D_{c}}\left(\ln R+\frac{1}{3}\right)\right\} \\
& \left.-\frac{R^{2}}{2 D_{c}}\left\{(L-2 R) \frac{r_{c}^{2}}{R^{2}}+2 R \frac{r_{c}^{3}}{R^{3}}\right\} \ln r_{c}\right]
\end{aligned}
$$

ここで、 $\mathrm{C}_{\mathrm{B}}$ はブリケットのモル濃度、 $\mathrm{C}_{0}$ は䨌囲気中の酸 素モル濃度、 $r_{c}$ は未反応核の半径である。ブリケットから チャー燃焼へ移行するときの粒子半径は変化しないと仮定 L、 $\mathrm{C}_{\mathrm{B}}\left[\mathrm{mol} / \mathrm{m}^{3}\right]$ は工業分析結果から $10 \%$ の固定炭素分が 全て炭素で構成されるとした。また、 $\mathrm{C}_{0}\left[\mathrm{~mol} / \mathrm{m}^{3}\right]$ は、䨌囲 気中の酸素分圧 $\mathrm{p}[\mathrm{Pa}]$ 、周囲空気温度 $\mathrm{T}[\mathrm{K}]$ を用いて、以下 の值を用いた。

$$
\begin{aligned}
C_{0} & =\frac{p}{T R_{0}}=\frac{0.21 \times 1.01325 \times 10^{5}}{673 \times 0.082 \times 1.01325 \times 10^{2}} \\
& =3.81\left[\mathrm{~mol} / \mathrm{m}^{3}\right] \\
{\left[R_{0}\right.} & \left.=0.082 \times 1.01325 \times 10^{2}\left[\frac{\mathrm{J}}{\mathrm{mol} \cdot \mathrm{K}}\right]\right]
\end{aligned}
$$

実験で得られたブリケット直径 $\phi 30 \mathrm{~mm} 、 \phi 35 \mathrm{~mm} 、 \phi 40$ $\mathrm{mm}$ におけるチャー燃焼継続時間をそれぞれで (6) 式に代入

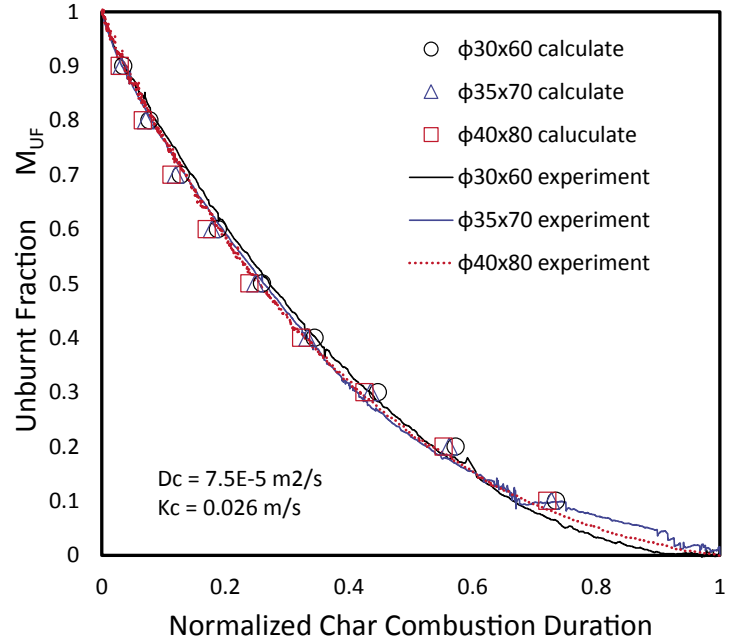

Fig.10 Unburnt Fraction of Briquette in Char Combustion.

して得られる 3 つの式の未知数 Kc および Dc を、実験結果 との差異が最小になるよう決定した。また、(6) 式の $r_{\mathrm{c}}$ を ブリケット未反応率 $\mathrm{M}_{\mathrm{UF}}$ から (8) 式の関係より与え、チャー 燃焼時の無次元質量減少を算出して Fig.10に実験結果とあ わせて示す。

$$
M_{U F}=\frac{\pi r_{c}^{2}\left\{L-2\left(R-r_{c}\right)\right\}}{\pi R^{2} L}
$$

本研究（密度 $1300 \mathrm{~kg} / \mathrm{m}^{3}$ 、製造時 $423 \mathrm{~K}$ 加熱）では、

$$
\begin{aligned}
& \mathrm{Dc}=7.5 \times 10^{-5}\left[\mathrm{~m}^{2} / \mathrm{s}\right] \\
& \mathrm{Kc}=2.6 \times 10^{-2}[\mathrm{~m} / \mathrm{s}]
\end{aligned}
$$

と見積られた。この結果は、呂ら ${ }^{17)}$ の $1000\left[\mathrm{~kg} / \mathrm{m}^{3}\right]$ のバイ オマスブリケット（製造時非加熱）の結果 $\left(\mathrm{Dc}=1.48 \times 10^{-4}\right.$ $\left.\left[\mathrm{m}^{2} / \mathrm{s}\right] 、 \mathrm{Kc}=3.0 \times 10^{-2}[\mathrm{~m} / \mathrm{s}]\right)$ と比較すると、灰層内の酸素の 有効拡散係数 Dc が小さいことがわかる。製造時加熱の影 響は明らかではないが、本研究で使用したブリケットの方 が密度が大きいためチャー燃焼時のブリケット内空隙も小 さく、結果として拡散係数が小さくなったものと考えられ る。Fig.10において実験結果と計算結果の一致は良く、本 研究で用いたモデルで比較的良くチャー燃焼の挙動を表す ことが可能であることを示している。

\section{7. 結 言}

ブリケット製造時に圧縮とともに加熱を行った、密度お よび水分率一定かつ直径：長さ比一定の高密度ブリケッ 卜 $(\phi 30 \mathrm{~mm} \times 60 \mathrm{~mm} \sim \phi 40 \mathrm{~mm} \times 80 \mathrm{~mm})$ の有炎燃焼および チャー燃焼挙動へのブリケットサイズの影響を調べ、以下 のことがわかった。

(1) 有炎燃焼継続時間は、比表面積の二乗に反比例する。 
(2) 有炎燃焼継続時間で時間を無次元化した有炎燃焼期間 の無次元質量減少速度はブリケットサイズによらずほ ぼ同様の履歴を示す。

（3）チャー燃焼継続時間も、概ね比表面積の二乗に反比例 する。

(4) チャー燃焼時の質量減少は、円柱を考慮した未反応核 モデルで比較的良く表現できる。本研究では、灰層内 の酸素の有効拡散係数 Dc $=7.5 \times 10^{-5}\left[\mathrm{~m}^{2} / \mathrm{s}\right]$ 、ガス境膜に おける酸素の有効拡散係数 $\mathrm{Kc}=2.6 \times 10^{-2}[\mathrm{~m} / \mathrm{s}]$ と見積も られた。

\section{謝 辞}

本研究は、平成 26 年度文部科学省科学研究費助成事業 (学 術研究助成基金助成金）（基盤研究 (C)）＃26420160）の支 援で行われた、ここに記して謝意を表する。

\section{引用文献}

1）環境省 HP http://www.env.go.jp/press/101818.html

2) 日本エネルギー学会編、バイオマスハンドブック（第 2 版）、 オーム社、2.

3) I.Adánez-Rubio, A.Abad, P.Gayán, L.F.de Diego, F.García-Labiano and J.Adánez: Fuel Processing Technology 124 (2014) 104-114.

4) S. Czernik and A.V.Bridgwater: Energy\&Fuels 18 (2004) 590-598.

5) 奥村幸彦、岡崎健：日本機械学会論文集（B 編）73-731 (2007) 1434-1441.
6) 川見佳正、桑名一徳、井田民男、水野諭、森田明宏: 高温学会誌、 35-2 (2009) 97-101.

7) 井田民男：日本燃焼学会誌、57-181 (2015) 214-221.

8) S.H.Sengar, A.G.Mohod, Y.P.Khandetod, S.S.Patil and A.D.Chendake: International Journal of Energy Engineering 2(1) (2012) 28-34.

9) K.B.Deepak and N.A.Jnanesh: International Journal of Science and Research (Online) 2319-7064.

10) S.J.Mitchual, K.Frimpong-Mensah and N.A.Darkwa: Journal of Sustainable Bioenergy Systems 4 (2014)50-60.

11) H.Ito, Y.Sakai, T.Ida, Y.Nakamura and O.Fujita: Journal of Thermal Science and Technology 6-1 (2011) 111-122.

12) T.Nakahara, H. Yan, H. Ito and O. Fujita: Proceedings of the Combustion Institute, 35-2 (2015) 2415-2422.

13) O.C.Chin and K.M.Siddiqui: Biomass and Bioenergy 18 (2000) 223228.

14) J.Chaney: Thesis for degree of doctor of Philosophy, The University of Nottingham, French (2010) 1-225.

15）奥村幸彦、渡部弘達、岡崎健 : 日本機械学会論文集（B 編） 79-799 (2013-3) 465-476.

16) 小川邦康：見える伝熱工学 (初版第 2 刷)、コロナ社 (2013) 31-33, 175-184.

17) 呂国慶、外山哲也、金熙濬、成瀬一郎、大竹一友 : 化学工学 論文集、23-3 (1997) 404-412.

18) J.Porteiro, J.L.Míguez, E.Granada and J.C.Moran: Fuel Processing Technology 87 (2006) 169-175. 